\title{
Binucleate cell migration in the bovine placentome
}

\author{
F. B. P. Wooding and D. Claire Wathes* $\dagger$ \\ A.R.C. Institute of Animal Physiology, Babraham, Cambridge CB2 4AT, and \\ * Department of Physiology and Environmental Studies, University of Nottingham, \\ School of Agriculture, Sutton Bonington, Loughborough, Leics LE12 5RD, U.K.
}

\begin{abstract}
Summary. The ultrastructure of cow placentomes, collected between 37 and 260 days of gestation, was examined. The microvillar junction and binucleate cell granules were selectively stained by phosphotungstic acid. Fetal binucleate cells interrupted the microvillar junction and penetrated as far as the basement membrane of the uterine epithelium. The uterine epithelium included not only binucleate cells which contained the distinctive granules but also non-granulated binucleate cells with pyknotic nuclei at the microvillar junction. Binucleate cells with pyknotic nuclei were also seen within chorion cells. It is suggested that the normal function of a mature chorionic binucleate cell at all the stages of bovine pregnancy is migration into the uterine epithelium to release its granules and subsequent condensation to a cell remnant which is phagocytosed by the chorionic epithelium.
\end{abstract}

\section{Introduction}

Large granulated binucleate cells first appear in the bovine chorionic epithelium when the embryo is 16-17 days old and they are present throughout the remainder of gestation (Greenstein, Murray \& Foley, 1958; Bjorkman, 1968). Interest in these cells has increased with the recent demonstration that similar cells in sheep contain ovine placental lactogen (Martal, Djiane \& Dubois, 1977). Flint, Henville \& Christie (1979) were able to detect bovine placental lactogen in cow conceptuses on Day 17 post coitum and they suggested that this was related to binucleate cell formation.

Following implantation the uterine epithelium also contains multinucleate giant cells, but these are generally thought to have a separate origin (Bjorkman \& Bloom, 1957; King, Atkinson \& Robertson, 1979). There is considerable controversy in both the cow and the sheep as to whether the fetal binucleate cells cross or even contact the microvillar junction. Amoroso (1952) presented evidence that binucleate cell migration does occur in the cow although the majority of other papers to which he referred disagreed with this view. King et al. (1979) have claimed that fetal binucleate cells are always separated from the microvillar junction by surrounding mononucleate chorionic epithelial cells.

The migration of fetal chorionic cells into the maternal component of the placenta has been demonstrated in a number of other species such as the horse (Allen, Hamilton \& Moor, 1973), man (Boyd \& Hamilton, 1960), rat and ferret (Enders \& Schlafke, 1969). The present study was conducted to determine whether such migration does occur in the mature cow placenta.

\section{Materials and Methods}

Eight Friesian cows between 37 and 260 days of gestation were slaughtered by captive bolt pistol and exsanguination. The reproductive tract was obtained within $20 \mathrm{~min}$ of death. For those animals in the first half of pregnancy (37-112 days) the entire uterus was perfused at room

$\dagger$ Present address: Department of Anatomy, The Medical School, Bristol BS8 1TD, U.K. 
temperature via the uterine arteries for about $15 \mathrm{~min}$. The fixative used was $4 \%$ glutaraldehyde in $0 \cdot 1 \mathrm{M}$-phosphate buffer, $\mathrm{pH} 7 \cdot 2$, containing $2 \%$ glucose (4G2P). Following perfusion additional fixative was injected into the uterine lumen at a number of sites. The uterus was then sliced into $3-5 \mathrm{~cm}$ sections which were left in fresh fixative for $2 \mathrm{~h}$. Small areas of placentome were carefully removed and were stored at $4^{\circ} \mathrm{C}$ in phosphate buffer. For cows in later stages of pregnancy entire placentomes were removed after slaughter and perfused with 4G2P via the fetal chorionic or maternal uterine arteries for $15 \mathrm{~min}$. The placentomes were then cut into matchstick-sized pieces $(\sim 2 \times 2 \times 30 \mathrm{~mm})$, each running the full length of the placental villi. These were placed in fresh fixative for $1 \mathrm{~h}$ before storage in phosphate buffer.

Material from each cow was processed in two different ways. Half the blocks (A) were post-fixed in $1 \%$ osmium tetroxide in $0.1 \mathrm{M}$-veronal acetate buffer, $\mathrm{pH} 7 \cdot 2$, for $1 \mathrm{~h}$ followed by $2 \%$ aqueous uranyl acetate for $30 \mathrm{~min}$. They were then dehydrated in alcohol and embedded in araldite as described by Wooding (1980). The remaining blocks (B) were dehydrated and embedded in the same way but the osmium tetroxide and uranyl acetate treatments were omitted.

Thin sections from both types of block were placed on celloidin-covered copper slots $(2 \times 1$ $\mathrm{mm}$ discs) and stained with uranyl acetate and lead citrate. In addition, thin sections from the $B$ blocks were placed on gilded copper slots and stained with $1 \%$ phosphotungstic acid (PTA) in $1 \mathrm{~N}-\mathrm{HCl}, \mathrm{pH} 0 \cdot 3$, followed in most cases by uranyl acetate (Wooding, 1980).

Estimates of the percentages of binucleate cells in the uterine and chorionic epithelia were made by counting nuclei in PTA-uranyl acetate stained sections in the electron microscope; at least 100 nuclei were counted on each section for all the animals.

\section{Results}

The micrographs in this paper were taken predominantly from placentomes of 49-day pregnant animals but the results were similar for all stages of pregnancy examined.

In the B blocks both the binucleate cell granules and the material at the microvillar junction between the chorionic and uterine epithelia stained intensely with PTA (P1. 1, Fig. 4). Very few of the other cell organelles were stained and this simplified the search for the granulated binucleate cells and clarified their relationship with the microvillar junction. Uranyl acetate staining was necessary after PTA to visualize cell boundaries (compare Pl. 1, Figs 1 and 4). In the A blocks the binucleate cell association with the microvillar junction was far more difficult to pinpoint and characterize (compare Pl. 1, Figs 1 and 2).

PTA also stained chromosomes in dividing cells and nuclei. Nuclear divisions were seen frequently in both the chorionic and uterine epithelia (Pl. 1, Fig. 3).

In the chorionic epithelium of cows 37-260 days pregnant, about $20 \%$ of the fetal cells were binucleate. Of these binucleate cells $80-90 \%$ were entirely surrounded by uninucleate chorionic cells, with no connection to the basement membrane or the microvillar junction (Pl. 1, Figs 1 and 3; Pl. 2, Figs 9 and 10; Pl. 3, Figs 14 and 15). The remaining 10-15\% of the binucleate cells formed part of the microvillar junction (Pl. 2, Figs 7 and 8; Pl. 3, Fig. 9). This junction consisted of interdigitating microvilli from the apposed chorionic and uterine epithelia, with the PTA-stained material attached to the outside of the chorionic cell plasmalemma (PI. 4, Fig. 13). Where a binucleate cell was in contact with the uterine epithelium the junction was smooth and the intensity of staining reduced (Pl. 2, Figs 5 and 8). The staining was entirely interrupted by binucleate cells which had inserted processes into the uterine epithelium (Pl. 2, Fig. 5; Pl. 3, Figs 8 and 9) or reached right down to the uterine epithelium basement membrane (Pl. 1. Figs 1, 2 and 4; Pl. 2, Figs 5 and 6; Pl. 3, Fig. 10) but they were never observed past this barrier.

The only organelles readily visible after PTA staining in the binucleate cells were the nuclei and the granules. The distinctive granules were membrane-bound, stained in a variety of 
intensities and were present in binucleate cells in both chorionic and uterine epithelia (Pl. 3, Figs 11 and 12). When the cells were midway between the chorionic and uterine epithelia the granules were usually in the fetal end of the cell (Pl. 1, Fig. 1, Pl. 3, Fig. 9); cells largely within the uterine epithelium had granules toward the basement membrane (maternal) end (Pl. 2, Fig. 5; Pl. 3, Fig. 10).

The uterine epithelium contained about $2 \%$ binucleate cells. A few stretched from the basement membrane to the microvillar junction and these normally contained some of the distinctive granules (Pl. 4, Fig. 13). The majority had neither attachment to the basement membrane nor granules, their microvillar junction boundary was less corrugated than usual but stained with PTA (P1. 4, Fig. 14). The nuclei of such cells stained much more densely than the adjacent cells and there was very little cytoplasm (Pl. 4, Figs 13 and 14). Cells entirely surrounded by PTA staining and containing two very dense nuclear remnants were found at the microvillar junction (Pl. 4, Fig. 15) and entirely within chorion cells (Pl. 4, Fig. 16). No uterine epithelial cells were seen with such inclusions.

\section{Discussion}

The data presented in this paper show that in the cow migration of binucleate cells continues throughout pregnancy, because a significant number of cells were found in intermediate position between the chorionic and uterine epithelia at all the stages examined. The distinctive granules have been used as a marker of the initial migration of the binucleate cell, and the binucleate condition and PTA-stained boundary as indicators of the subsequent fate of these cells.

Using the PTA staining technique a significant number of fetal binucleate cells have been localized in contact with the uterine epithelial cells at the materno-fetal (microvillar) junction. Wooding (1980) has reported similar results for sheep placentomes in which the uterine epithelium is replaced by a syncytial layer. Previous workers who have suggested that this contact does not occur in the cow (King et al., 1979) and the sheep (Boshier \& Holloway, 1977) were using osmium post-fixation and uranyl acetate-lead staining which make both the microvillar junction and the binucleate cells more difficult to visualize.

Amoroso (1952) concluded that fetal binucleate cells in both cows and sheep migrated into the uterine epithelium replacing the epithelium in the cow and forming the syncytium in sheep. No evidence to support this view has been found by the majority of subsequent workers (e.g. Bjorkman \& Bloom, 1957; Lawn, Chiquoine \& Amoroso, 1969; Boshier \& Holloway, 1977). Although Steven et al. (1978) suggested that the similarity in granule structure between binucleate cells and the sheep syncytial layer provided evidence for migration, they thought that in natural circumstances this was a rare event which occurred mainly in the early stages of pregnancy (up to 28 days). We have evidence from the sheep and the cow (D. C. Wathes \& F. B. P. Wooding, unpublished observations) that binucleate cell migration occurs as early as 18 and 20 days of gestation respectively.

Binucleate cells containing little cytoplasm and no granules have been observed previously in the uterine epithelium in the placentomes of cows between 30 and 270 days of gestation (Bjorkman, 1968; King et al., 1979). The fine structures of these cells was obviously dissimilar to that of the fetal binucleate cells and a separate origin was therefore suggested; this remains a possibility because mitosis can be observed in the uterine epithelium. An alternative explanation is that after migration the fetal binucleate cells release their considerable number of granules at the basement of the uterine epithelium, probably by exocytosis although no definitive evidence for this has yet been obtained. This loss of cytoplasmic volume together with some nuclear shrinkage could produce the binucleate cell residues found as part of the maternal side of the microvillar junction. Phagocytosis of these residues would result in the pyknotic binucleate cell 


\section{PLATES $1-4$}

Electron micrographs of the chorionic (black stars) and uterine (black asterisks) epithelia of the bovine placentome at different stages of gestation. The tissues were fixed and processed as described in the text; all were fixed with glutaraldehyde and embedded in araldite. The stains were phosphotungstic acid (PTA), lead citrate and uranyl acetate (UA). In all figures the microvillar junction between the chorionic and uterine epithelia is indicated by an arrowhead.

\section{PLATE 1}

Fig. 1. Day 49. There are five (1-5) binucleate cells in the chorionic epithelium; 1 is at an early stage before granule production; 2, 3 and 4 are mature, with characteristic PTA-stained granules and are separated by chorionic cell cytoplasm from the microvillar junction; 5 completely interrupts the PTA-stained microvillar junction and stretches down to the basement membrane of the uterine epithelium. PTA-UA, $\times 1400$.

Fig. 2. Day 49. A binucleate cell (B) interrupting the microvillar junction between the chorionic and uterine epithelia, equivalent in position to cell 5 in Fig. 1. After conventional fixation and staining at this magnification it is very difficult to recognize the microvillar junction or the characteristic granules in the binucleate cell. UA-lead citrate, $\times 1500$.

Fig. 3. Day 49. There are frequent cell divisions in the chorionic and uterine epithelia. PTA stains the chromosomes in dividing cells (arrows). PTA-UA, $\times 1000$.

Fig. 4. Day 49. After PTA staining alone it is difficult to distinguish cell boundaries. The binucleate cell (1) is mostly in the uterine epithelium but completely interrupts the microvillar junction and contains the characteristic granules (curved arrow) which also identify a binucleate cell (2) in the chorionic epithelium. PTA, $\times 1500$.

\section{PLATE 2}

Fig. 5. Day 37. Three binucleate and/or granulated cells can be seen; 1 bounded by chorion cells; 2 and 3 both interrupting the PTA staining of the microvillar junction-2 is on the chorionic side and 3 is wholly within the uterine epithelium. PTA, $\times 750$.

Fig. 6. Day 260. Binucleate cell 1 is separated by a very thin sheet of chorionic cell cytoplasm from the microvillar junction. Cell 2 is almost completely within the uterine epithelium with only a small tail forming a gap in the PTA stain at the microvillar junction. PTA, $\times 1900$.

Figs 7 and 8. Day 49. Binucleate cells with a narrow contact (Fig. 7) and a broader pseudopodial contribution (Fig. 8) to the microvillar junction. PTA-UA, $\times 2900$ (Fig. 7); $\times 3000$ (Fig. 8).

\section{PLATE 3}

Fig. 9. Day 49. Two binucleate cells; 1 lacking any contact with, and 2 with a broad interruption of, the microvillar junction staining. Note the process (curved arrow) from cell 2 passing between the uterine epithelial cells. PTA-UA, $\times 2300$.

Fig. 10. Day 49. Binucleate cell 1 has an extensive cytoplasm but no granules, probably representing an early developmental stage; 2 has many granules and a narrow contact with the microvillar junction (arrow); 3 is nine-tenths into the uterine epithelium and completely interrupts the PTA stain at the microvillar junction, leaving an eccentrically shaped tail on the chorinnic side. The granule distribution in cell 3 is towards the basement membrane of the uterine enithelium (curved arrow); compare with cell 5 in Fig. 1. PTA-UA, $\times 2300$.

Figs 11 and 12. Binucleate cells from the uterine (Fig. 11) and chorionic (Fig. 12) epithelia, showing the similarity of the characteristic PTA-stained granules which occur in various sizes. PTA-UA, $\times 38000$ (Fig. 11); 50000 (Fig. 12). 


\section{PLATE 1}
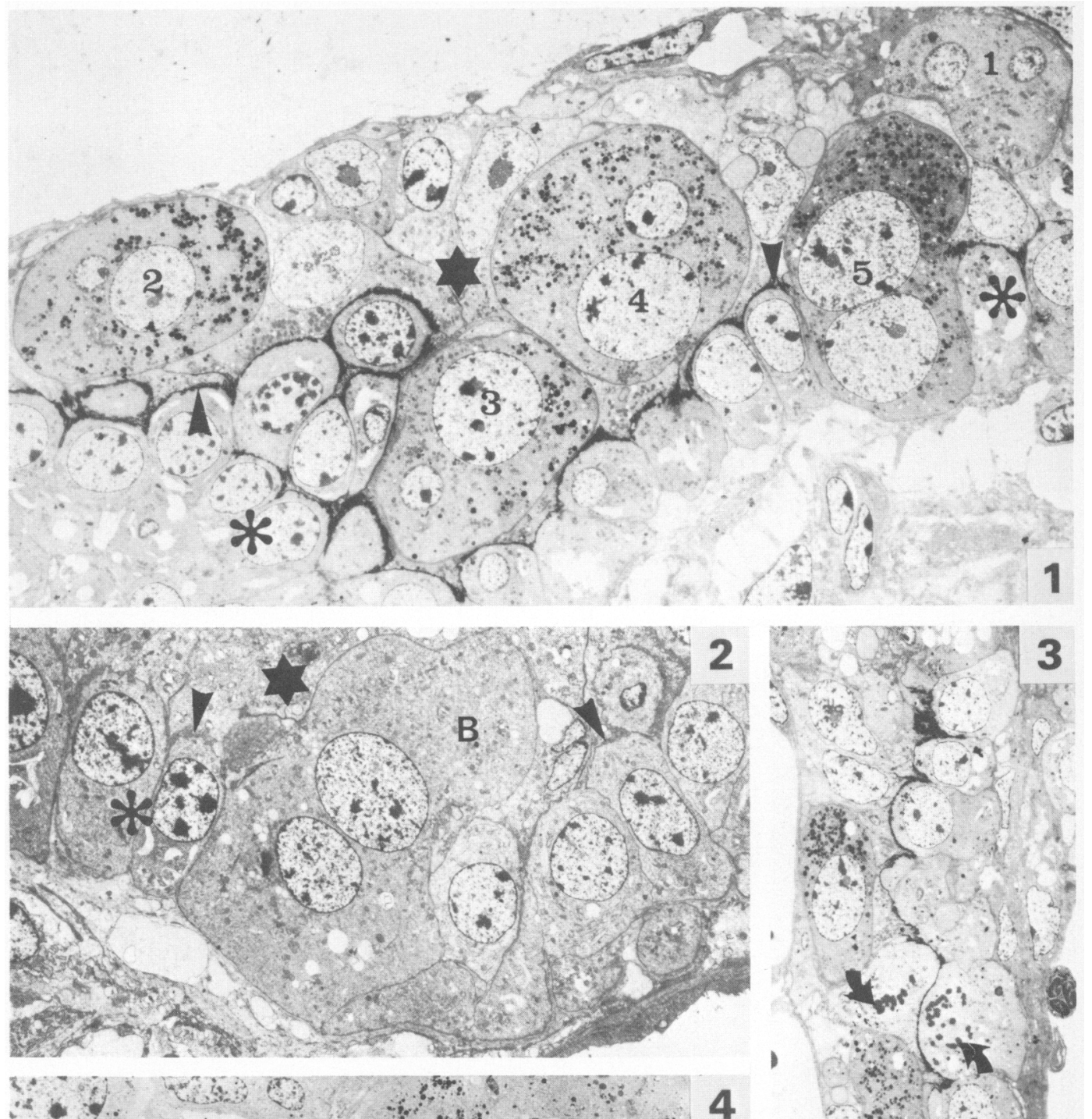

-. ${ }^{2} \cdot y^{4} \cdot \frac{4}{10}$

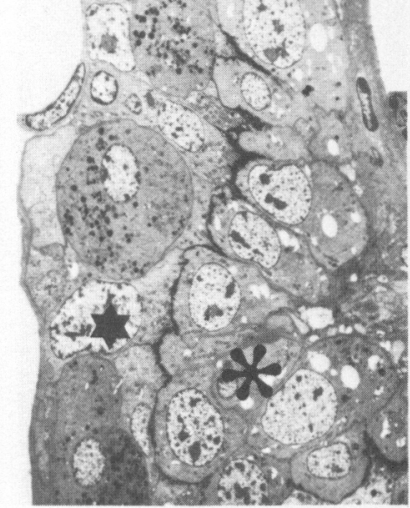


PLATE 2

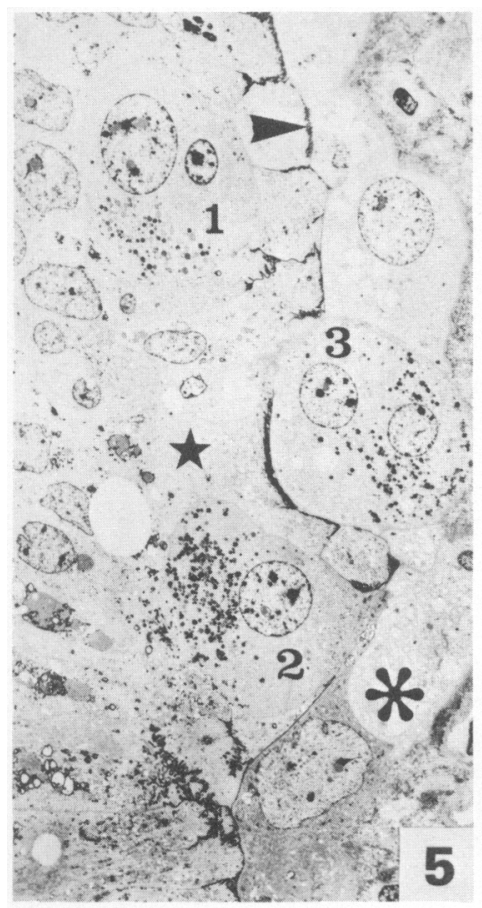

$\therefore \%$ :

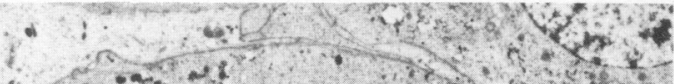

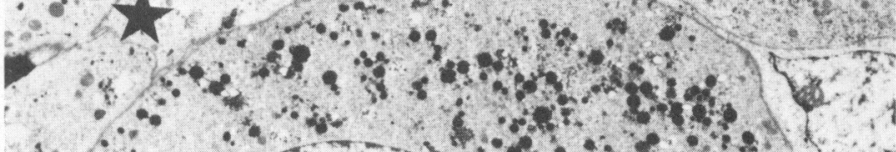

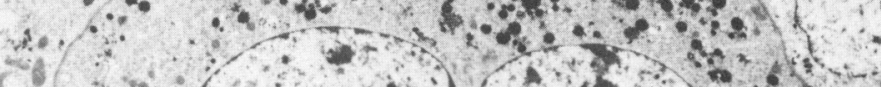

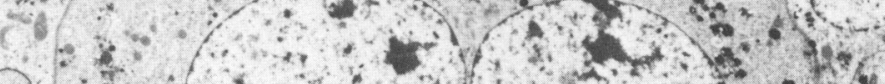

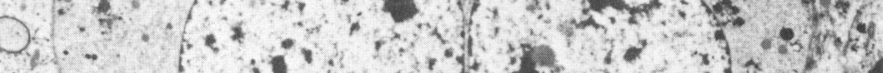

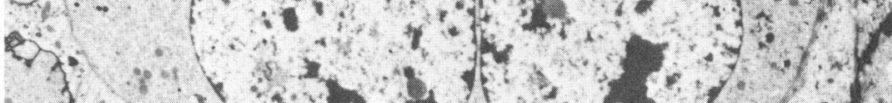

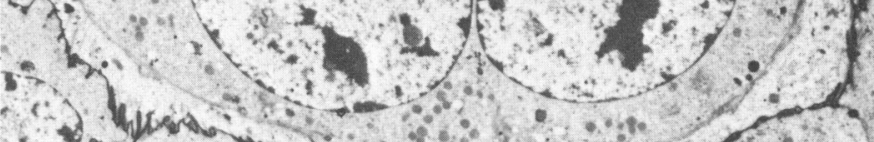

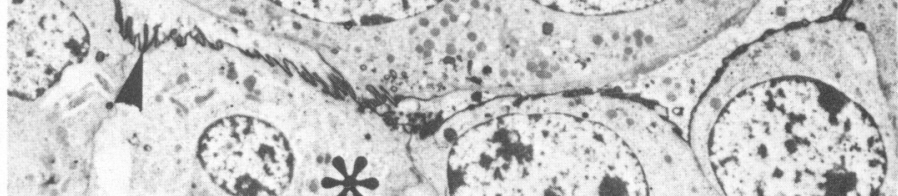

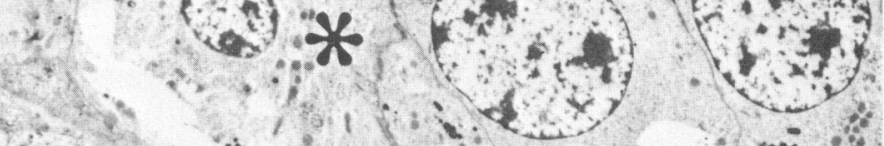

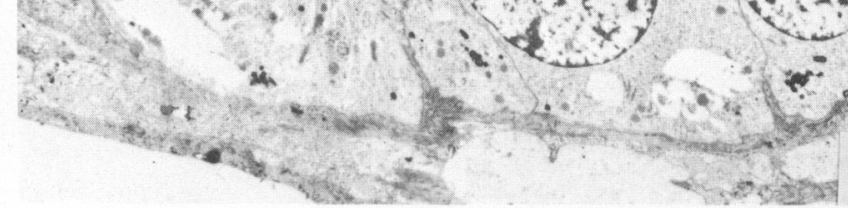

\section{7}

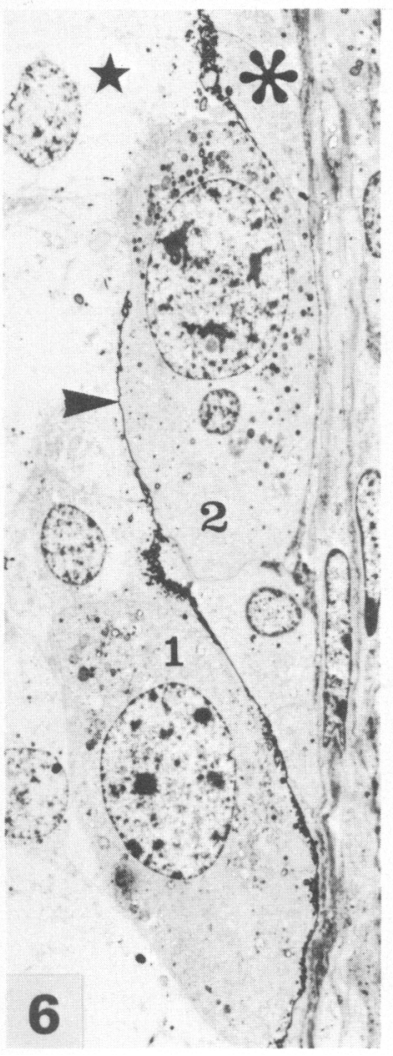

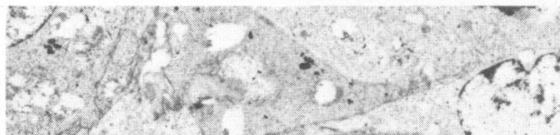

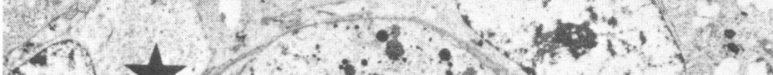

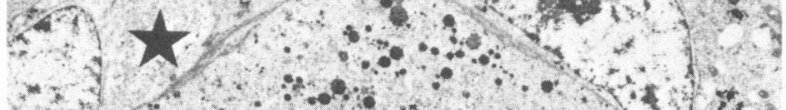

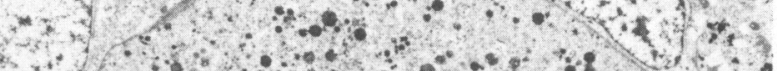

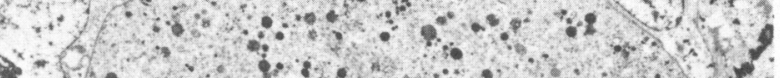

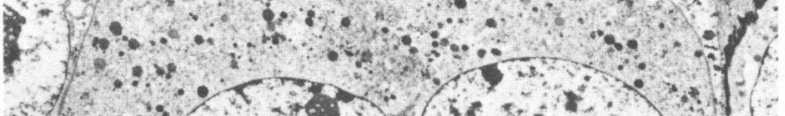

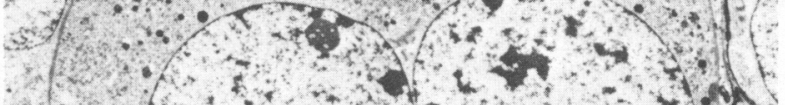

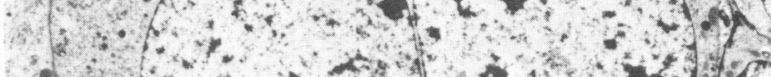

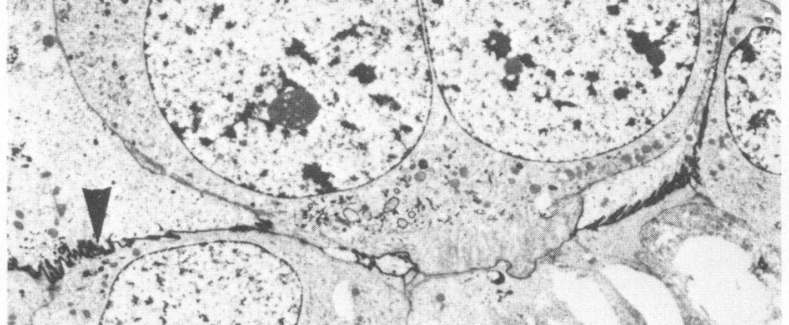

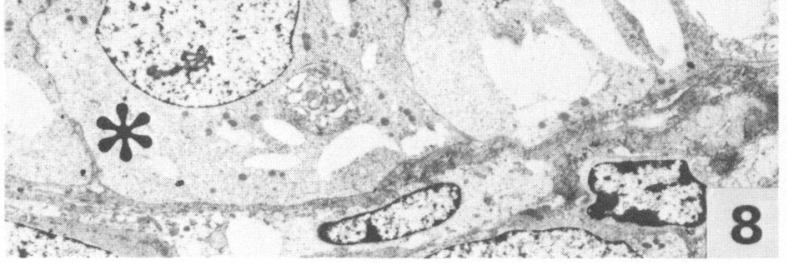


PLATE 3

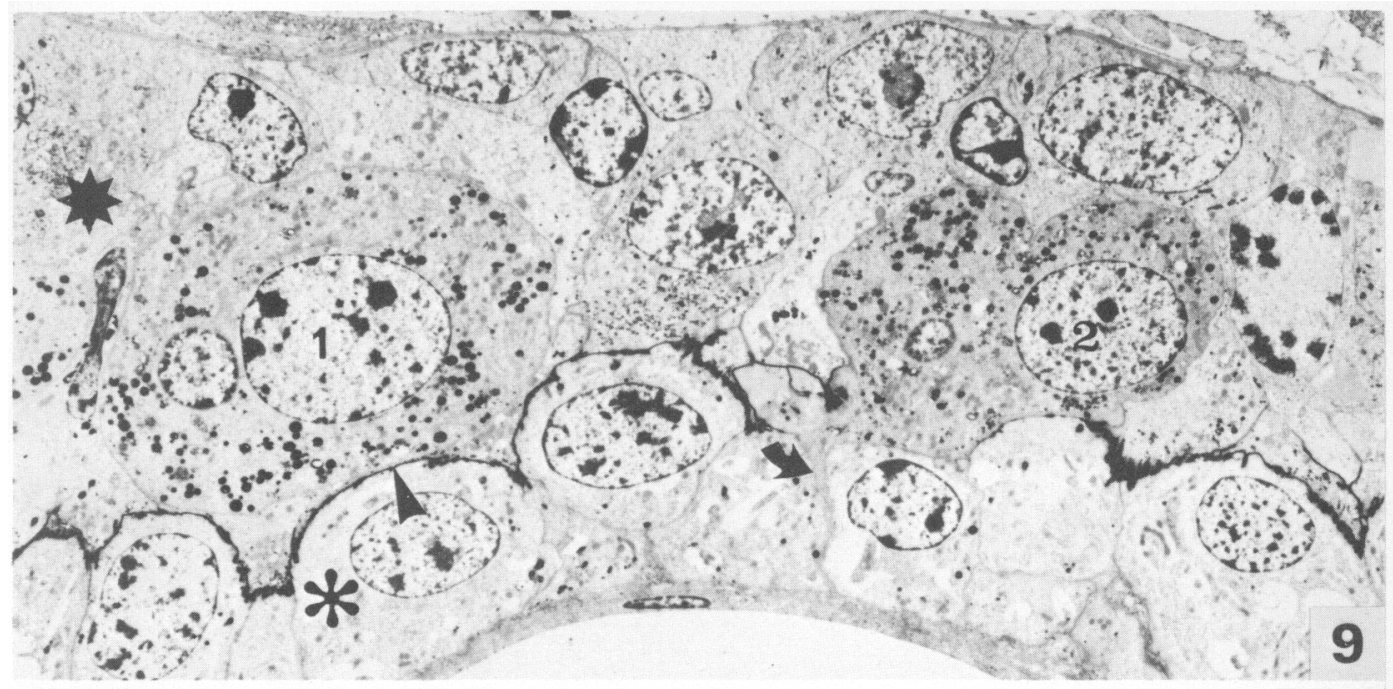

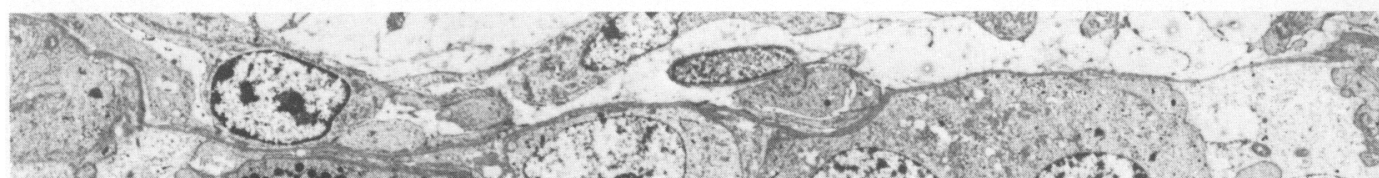

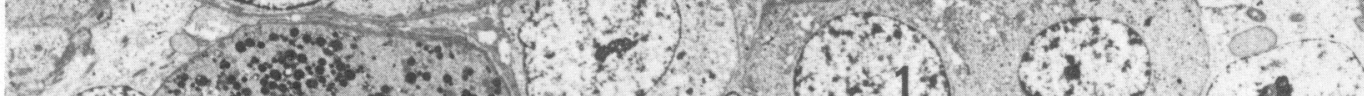

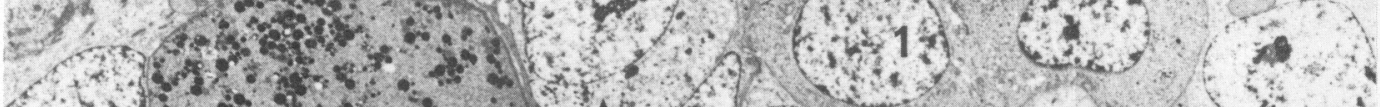

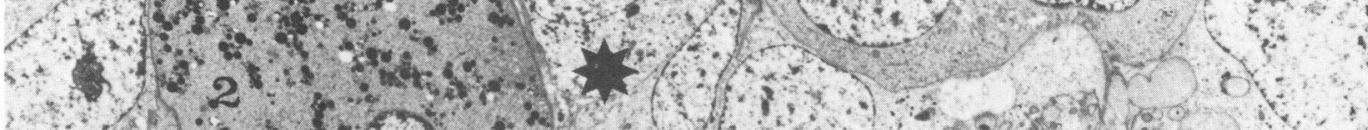

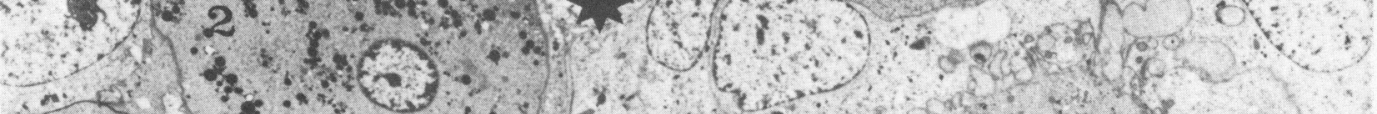

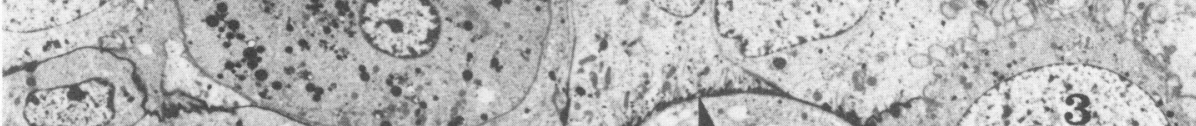

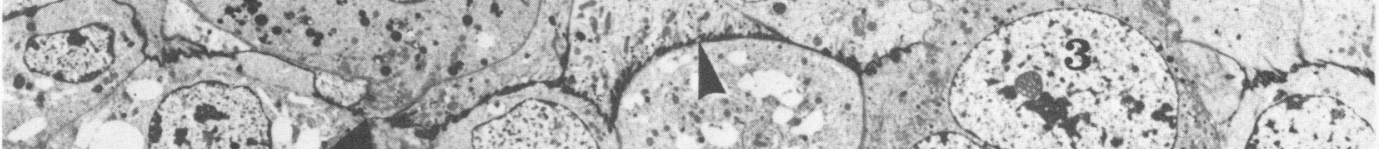

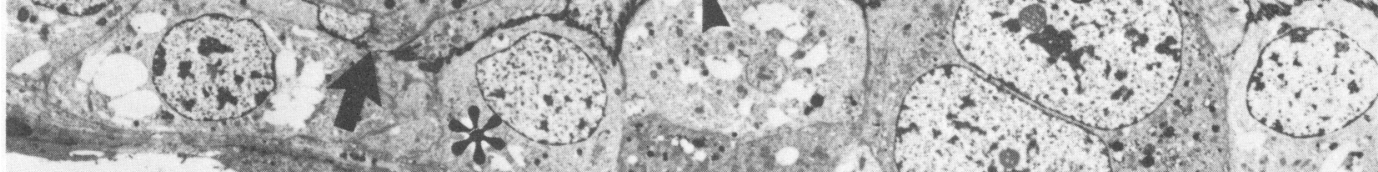

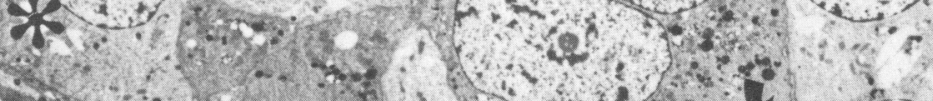

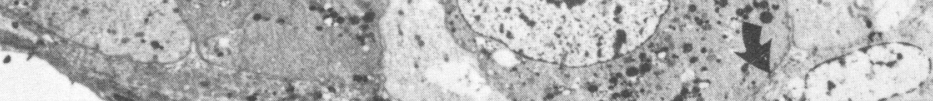

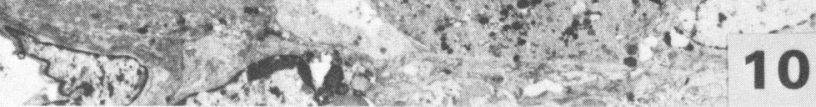
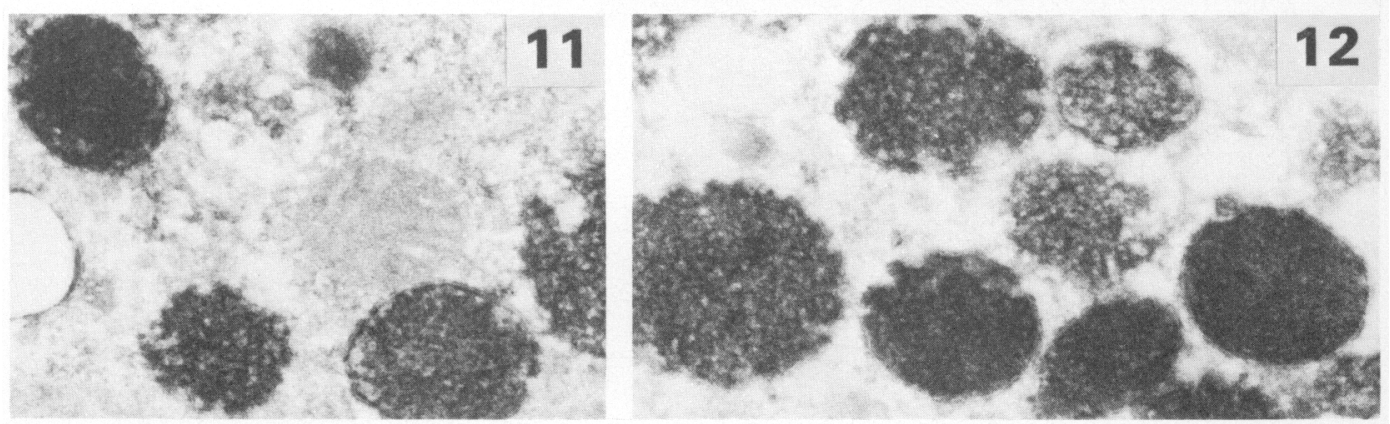


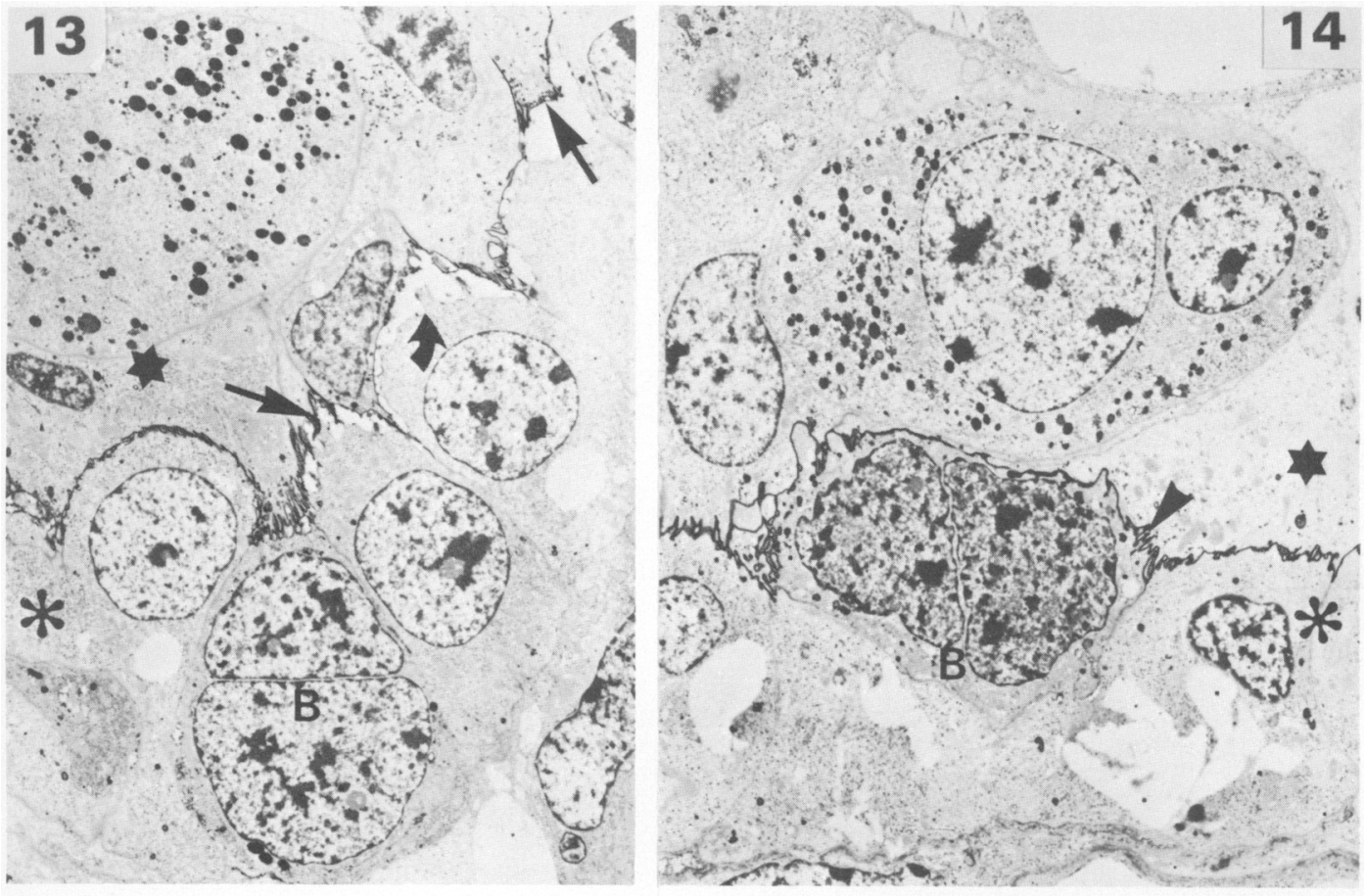

mit well

(2)

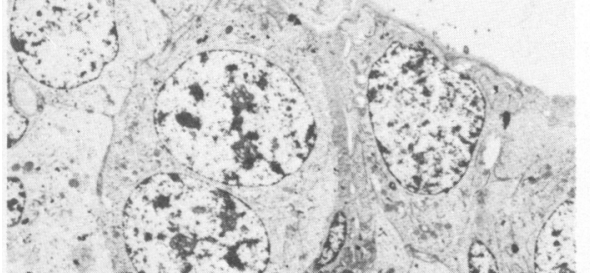

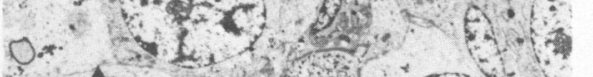

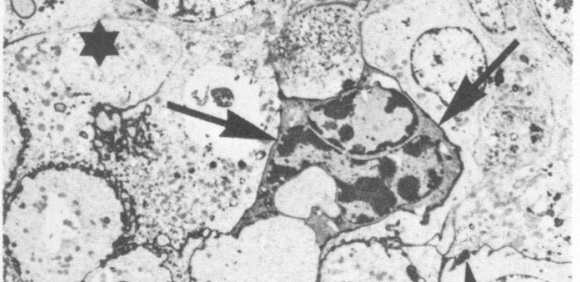

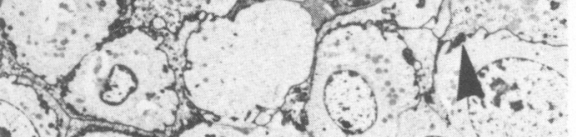
1) * * $4 x+4$

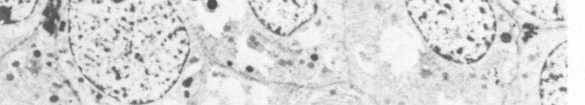
$x^{2}-8, \quad 00$

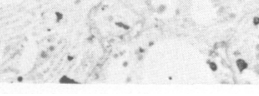

\section{5}

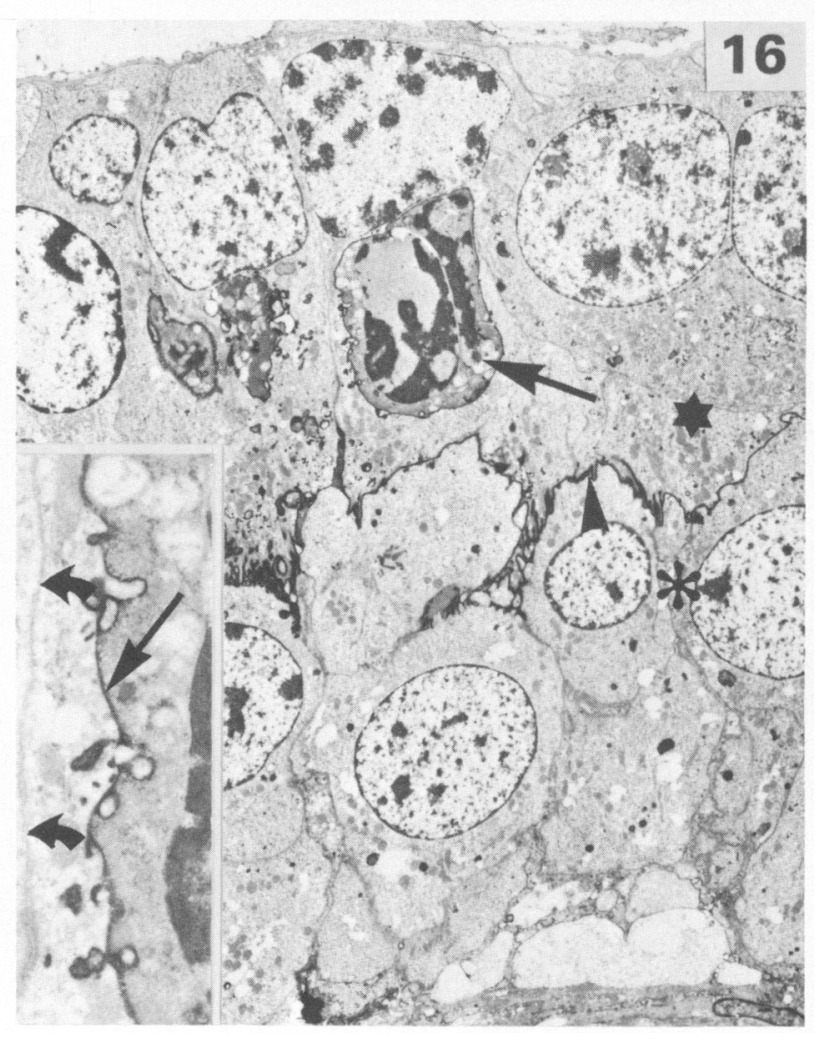


remnants bounded by PTA-stained membranes which can be found in the chorion cells. A diagrammatic representation of our concept of binucleate cell migration is given in Text-fig. 1 .

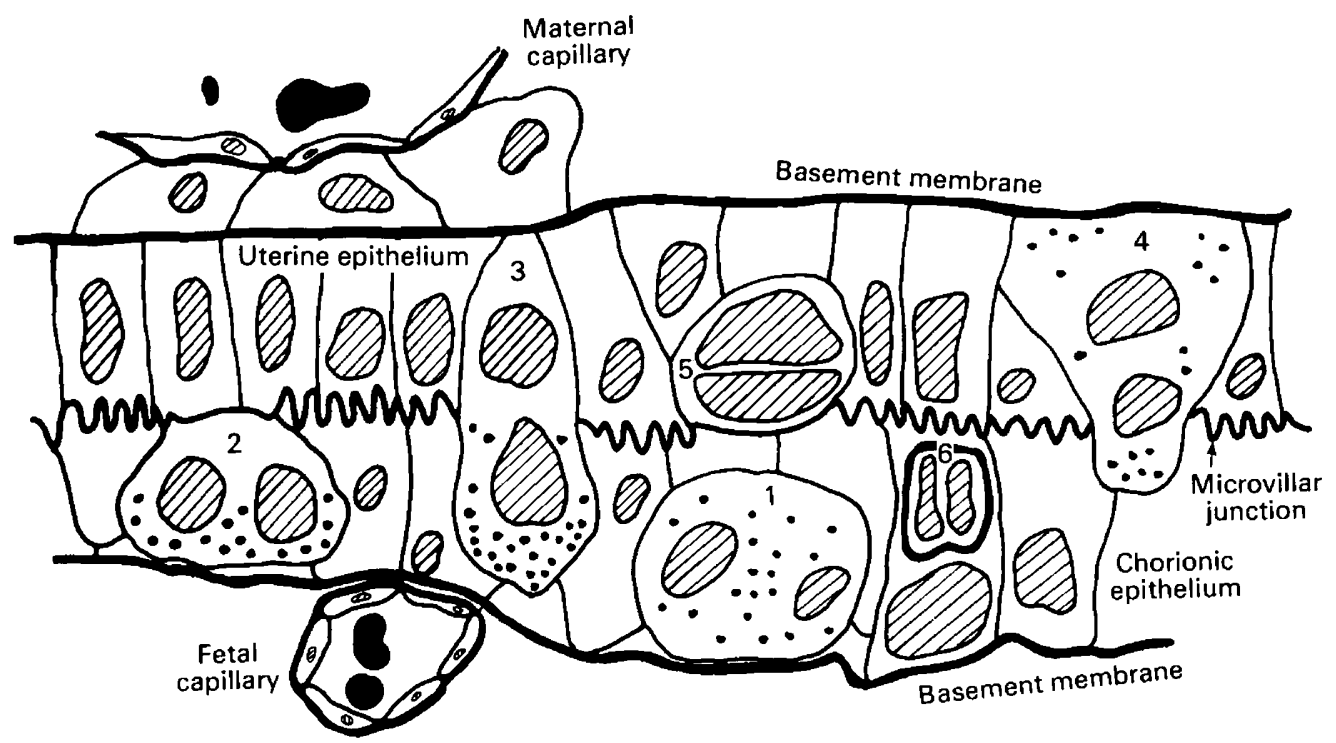

Text-fig. 1. Diagrammatic representation of the possible stages involved in binucleate cell migration. (1) Fetal binucleate cell is formed in the chorion and synthesizes granules. (2) It moves towards and makes contact with the microvillar junction. (3) It crosses the junction and reaches the basement membrane of the uterine epithelium. The granules are in the fetal end of the cell. (4) The majority of the cell is located in the uterine epithelium. The granules are scattered throughout the cell or at the maternal end of the cell. (5) Maternal binucleate cell with reduced cytoplasm, no granules and shrunken, dense nuclei. Where its boundary forms part of the microvillar junction, it is densely stained with PTA. Other binucleate remnants at the microvillar junction are entirely surrounded by PTA staining. (6) Binucleate cell remnant, with very shrunken dense nuclei in a chorion epithelial cell vacuole. The vacuole is bounded by PTA staining.

It is likely that the staining reaction of PTA at $\mathrm{pH}<1.0$ demonstrates the presence of glycoproteins and/or basic proteins (Quintarelli, Bellocci \& Geremia, 1973). The exact nature of the material at the microvillar junction and in the binucleate cell granules which is shown by this

\section{PLATE 4}

Fig. 13. Day 49. The characteristic binucleate cell (B) in the uterine epithelium has few, if any, granules and little cytoplasm. It stretches from the basement membrane to the microvillar junction. In this figure there is a slight separation at the junction and it can be seen that the PTA stains material on the chorionic microvilli only (arrows); the uterine epithelial surface is unstained (curved arrow). PTA, $\times 3000$.

Fig. 14. Day 49. A uterine epithelial binucleate cell (B) with rather pyknotic nuclei and virtually no cytoplasm and no contact with the basement membrane. The cell forms a rather flat microvillar junction, heavily stained with PTA. PTA, $\times 2800$.

Fig. 15. Day 49. A binucleate pyknotic cell remnant at the microvillar junction surrounded by PTA-stained membrane (arrows). PTA-UA, $\times 1900$.

Fig. 16. Day 49. A binucleate pyknotic cell residue (arrow) wholly within a vacuole in a chorionic cell. $\times 3000$. Insert: the PTA-stained vacuole boundary (large arrow) with the virtually unstained chorionic cell lateral plasmalemmas (curved arrows). PTA-UA, $\times 12500$. 
technique remains to be determined. There is no reason to suppose that substances stained at the two locations are identical although they may belong to a similar chemical species such as glycoprotein.

Martal et al. (1977) have demonstrated by immunofluorescent techniques that ovine placental lactogen can be localized in sheep binucleate cells and bovine placental lactogen has been found in the cow conceptus as early as Day 17 of gestation (Flint et al., 1979) and has been measured in cotyledonary tissue throughout pregnancy (Buttle \& Forsyth, 1976). It is possible that binucleate cell migration is required in the cow to transfer a large, non-diffusible molecule such as placental lactogen across the microvillar junction as has been suggested for the sheep by Steven et al. (1979).

We thank the Milk Marketing Board of England \& Wales for generous financial support. The technical assistance of Mr G. Morgan and Mrs J. Buckle and the encouragement of Professor G. E. Lamming during the project is gratefully acknowledged.

\section{References}

Allen, W.R., Hamilton, D.W. \& Moor, R.M. (1973) The origin of equine endometrial cups II. Invasion of the endometrium by trophoblast. Anat. Rec. 177, 485502.

Amoroso, E.C. (1952) Placentation. In Marshall's Physiology of Reproduction, 3rd edn, Ch. 15, pp. 127-311. Ed. A. S. Parkes. Longmans Green, London.

Bjorkman, N.H. (1968) Fine structure of cryptal and trophoblastic giant cells in the bovine placentome. $J$. Ultrastruct. Res. 24, 249-258.

Bjorkman, N.H. \& Bloom, G. (1957) On the fine structure of the foetal-maternal junction in the bovine placentome. Z. Zellforsch. mikrosk. Anat. 45, 649 659.

Boshier, D.P. \& Holloway, H. (1977) The sheep trophoblast and placental function: an ultrastructural study. J. Anat. 124, 287-298.

Boyd, J.D. \& Hamilton, W.J.H. (1960) The giant cells of the pregnant human uterus. J. Obstet. Gynaec. Br. Emp. 67, 208-218.

Buttle, H.L. \& Forsyth, I. (1976) Placental lactogen in the cow. J. Endocr. 68, 141-146.

Enders, A.C. \& Schlafke, S.S. (1969) Cytological aspects of trophoblast-uterine interaction in early implantation. Am. J. Anat. 125, 1-30.

Flint, A.P.F., Henville, A. \& Christie, W.B. (1979) Presence of placental lactogen in bovine conceptuses before attachment. J. Reprod. Fert. 56, 305-308.
Greenstein, J.S., Murray, R.W. \& Foley, R.C. (1958) Observations on the morphogenesis and histochemistry of the bovine pre-attachment placenta between 16 and 33 days of gestation. Anat. Rec. 132, 321-341.

King, G.J., Atkinson, B.A. \& Robertson, H.A. (1979) Development of the bovine placentome during the second month of gestation. J. Reprod. Fert. 55, $173-180$.

Lawn, A.M., Chiquoine, A.D. \& Amoroso, E.C. (1969) The development of the placenta in the sheep and goat: an electron microscopic study. J. Anat. 105, $557-578$.

Martal, J., Djiane, J. \& Dubois, M. (1977) Localisation by immunofluorescence of ovine placental lactogen. Cell. Tissue Res. 184, 427--433.

Quintarelli, G., Bellocci, M. \& Geremia, R. (1973) On phosphotungstic acid staining: IV the selectivity of the staining reaction. J. Histochem. Cytochem. 21, $155-160$.

Steven, D.H., Bass, F., Jansen, C.J.M., Krane, E.J., Mallon, K., Samuel, C.A., Thomas, A.L. \& Nathanielz, P.W. (1980) Ultrastructural changes in the placenta of the ewe after fetal pituitary stalk section. Q. Jl exp. Physiol. 63, 221-229.

Wooding, F.B.P. (1980) Electron microscopical localisation of binucleate cells in the sheep placenta using phosphotungstic acid. Biol. Reprod. (In press). 